\title{
Creative Cities and the Film Industry: Antalya's Transition to a Eurasian Film Centre
}

\author{
Bahar Durmaz ${ }^{1}$, Tan Yigitcanlar ${ }^{*}, 2$ and Koray Velibeyoglu ${ }^{1}$ \\ ${ }^{I}$ Department of City and Regional Planning, Izmir Institute of Technology, Izmir, Turkey \\ ${ }^{2}$ School of Urban Development, Queensland University of Technology, Brisbane, Australia
}

\begin{abstract}
In the knowledge era, cites are competing to attract and retain creative industries and workers for securing their economic, social and urban growth as well as ensuring their creative city formation. During the last decade rapidly growing popularity of creative cities has encouraged many cities seeking creativity to specialise in specific sectors of the creative industries. In this context, the paper explores creativity strategies and the role of film industry in creative city formulation. Antalya, Turkey is investigated as an emerging film industry-oriented creative city due to recent industry developments, its natural and constructed assets and amenities along with its openness to creativity. This paper also examines some of the creative city examples, scrutinises potentials and constraints of Antalya and Turkish film industry, and provides discussion and recommendation for Antalya's transition to a Eurasian film centre.
\end{abstract}

\section{INTRODUCTION}

Throughout the last two centuries many cities transformed their economies from an agricultural-based economy to an industrial-based one, and last two decades witnessed the transformation of these industrial-based economies into knowledge-based ones [1, 2]. In a knowledge-based economy human capital is regarded as an engine of economic and social growth, and has gained equivalent importance to $\mathrm{fi}$ nancial capital [3]. In the knowledge era, the human capital theory is now replaced with the theory of creative capital, which primarily concerns creative people, the creative class (e.g. professionals in architecture, arts, design, and media), as the source of creativity [4]. In this new era, creativity concept is also gaining an increased prominence amongst urban planners and policy makers, influencing the development strategies of cities, and luring the attention towards creative industries as a significant driver of urban growth [5].

The global examples demonstrate that the film industry, as one of the major sector of creative industries, is able to shape the development of cities, and contribute to the growth of tourism sector (i.e. Berlin, Cannes, Los Angeles). The literature shows that place-based concentrated creativity fosters uniqueness and distinctiveness of that place, and draws talent and investment by improving the reputation and attractiveness of that place [6]. However, the success of creative city and the film industry also depends on a well designed creativity vision and supporting strategies (i.e. place branding and place quality strategies), along with an overall success of the film and other supporting creative industry companies.

This paper aims to explore the role of film industry in the development of creative cities. The paper focuses on creative communities, creative industries, and creativity strategies as

*Address correspondence to this author at the School of Urban Development, Queensland University of Technology, Brisbane, Australia;

E-mail: tan.yigitcanlar@qut.edu.au the major building blocks of creative city formation. The following two sections discuss the creative turn in urban growth, current issues and trends in creative city formation, and the creative communities. The fourth section presents an outline of creativity strategies, and explores the superimposed strategies of place-based and talent-based policies. The fifth section focuses on creative industries, and investigates the increasing importance of this industry in the knowledge-based economy. The sixth section examines the film industry as one of the major sectors of creative industries. This section also scrutinises global examples of film industry-oriented creative cities, and specifically focuses on City of Antalya, Turkey, exploring its potential to become a film industry-oriented creative city, where the adventure has been started in 1957 by a famous Turkish film director's, Behlül Dal, vision of turning Antalya into a film city. As much as Istanbul, Antalya also has an important role to further developed the film industry in the country. Therefore, the paper concludes with a discussion on the potentials of Antalya to become a Eurasian film centre by improving its linkages with the current national film centre (Yesilcam, Istanbul) and international film centres across Asia, Europe and Northern America (i.e. Boolywood, Berlin, Hollywood).

\section{CREATIVE CITIES}

In recent years the concept of creativity has come to the agenda of urban planning and development, and given birth to a number of new concepts. Creative city, creative class, creative capital, creative economy, creative industries, creative milieu are among these new concepts used by many scholars and urban policy makers. Creativity is defined as "any act, idea, or product that changes an existing domain or that transforms an existing domain into a new one" (p.385) [7]. Creativity and cities are strongly linked with each other as "a creative milieu is a place - either a cluster of buildings, a part of a city, a city as a whole, or a region - that contains the necessary preconditions in terms of hard and soft infrastructure to generate a flow of ideas and inventions" (p.133) [5]. The knowledge-based economy promotes knowledge 
generation and creativity as the central activities of economic and urban growth mechanisms, and literature indicates a strong correlation between creative places and economic growth [4]. In other words success of cities in the knowledge era depends on how creative they are [8]. In recent years as urban regions have become the localities of key creative precincts and clusters across the globe, the link between a range of new creative industrial activities and the development of creative urban regions has become a hot topic of research [9]. For that reason creativity have garnered a lot of attention, and become one of the key concepts for city administrators and scholars who are in search of new ways in urban development to cope with the negative effects of globalisation and new emerging economic structures. In this regard, Kunzmann [7] sees the recent focus on creativity, culture, creative spatial planning, and creative governance in European cities as the (re)enlightenment project of Europe. Creativity and creative capital theories shift the emphasis from physical structures to individuals. As cultural resources are embodied in people's creativity, a creative city aims to create the conditions, which people think, plan, and act creatively [10]. This means providing an enabling environment that facilitates exchange of ideas, and possibility to turn these ideas into products, services, and innovative solutions to urban problems. Therefore, creativity should be supported for creative capacity to be captured and transformed into economic and social wealth for the development of a successful city and its competitive economy [11].

Basically, a creative city is an entity that could only be developed: through well designed creativity strategies (policy); with a strong presence of creative industries (economy) and; by a creative community (society). The logical connections between these three main building blocks of a creative city particularly specialising on the film industry is concep- tualised and illustrated in Fig. (1). The remainder of this paper focuses and discusses each of these building blocks and their supporting components.

\section{CREATIVE COMMUNITIES}

A creative person is defined as "someone whose thoughts or actions changes a domain, or establishes a domain" (p.385) [7], and the creative group of individuals, creative community or creative class, defined as the source of creative capital being an essential asset for cities' economic growth [4]. Creative class is commercialised as creative capital being the driver of innovation in a changing economy, pioneering ideas, high-tech industry, and regional growth, which are fundamentally needed for further progress [11]. This creative class theory has become so popular and discussed by many academics, implemented by city managers, and lead to new directions in place making, such as development of creative cities. However, Landry [10] criticises approaches solely considering the creative class, as a city should provide opportunities of creativity for all of its residents whether artists or scientists or ordinary citizens. In addition to this point, as well as attracting outside talent, cities need to achieve endogenous growth by harnessing the talent of its locals, expanding the creative community.

\section{CREATIVITY STRATEGIES}

Creative industries, creative class, culture of the spirit, aesthetic sense, and intellectual eminence are among the necessary structural elements of a creative city formation [13]. Ideally, the economy of creative cities is based on creative industries, and creative work is produced by the creative people, planners, researchers, open-minded and risk-taker developers $[5,7]$. It is essential to formulate or enhance creative industries as the main source of promoting creativity.

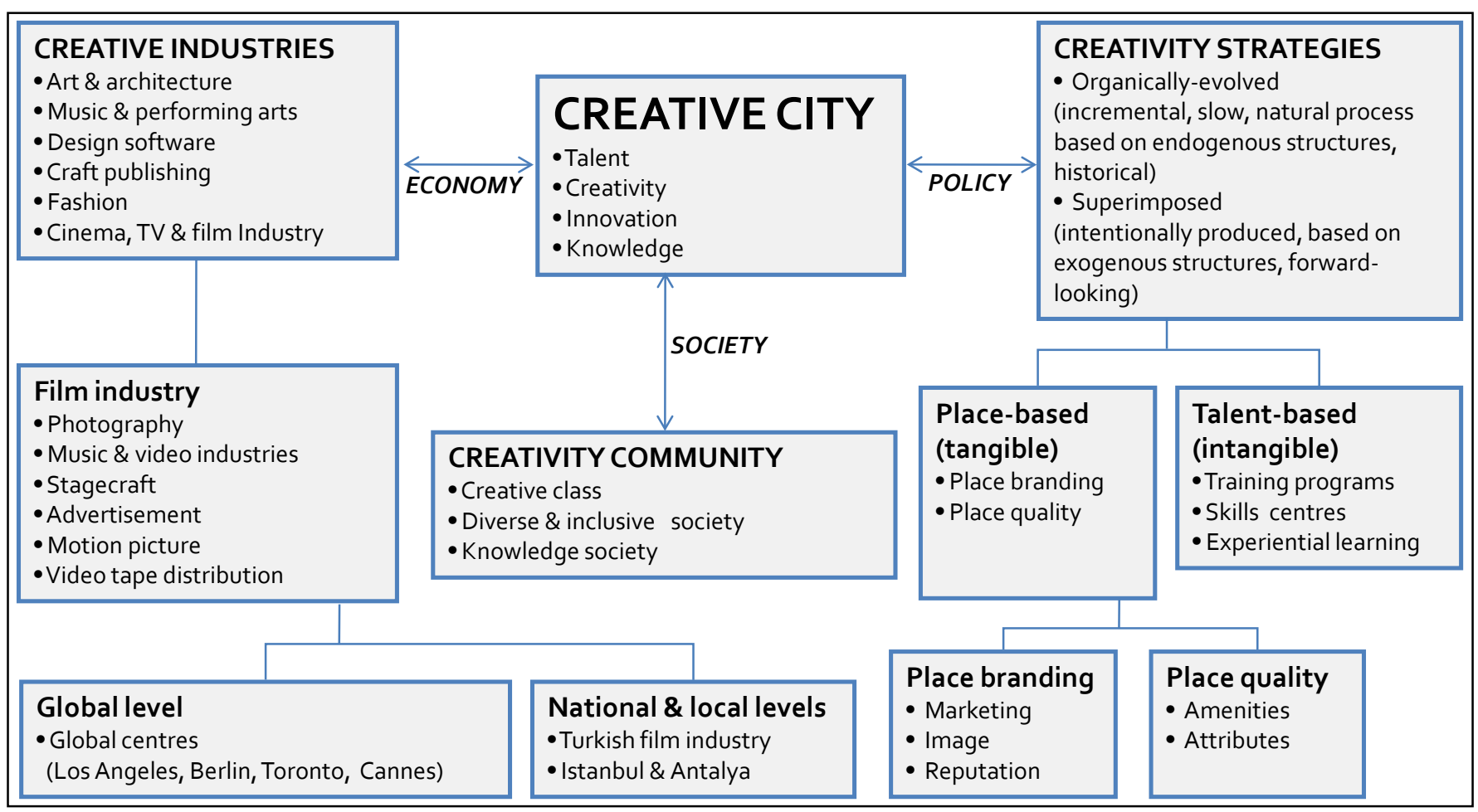

Fig. (1). Analysis framework of a film industry oriented creative [12]. 
Creative cities accommodate the physical, social and economical attributes that forms place quality to incubate creativity, and retain and attract creative people. Atkinson and Easthope [14] summarise the key conditions for the formation of a creative city by recapping the necessity of:

- $\quad$ High quality of life (including place quality).

- Highly educated and ethnically diverse population (creative class).

- High capital accumulation (economic, human, and cultural) to attract and retain creative industries.

Another important factor of creativity is distinctiveness which also plays a crucial role in terms of being competitive; and to be distinctive, creativity is needed. Distinctiveness is something unique or special and reputable covering all sorts of distinguishing characteristics of cities, and it is derived either organically or by superimposition [15]. The former is based on endogenous potentials of city such as built heritage, urban landscape, urban morphology and socio-cultural structure. According to this, distinctiveness is embedded in established structures and can be derived by incremental, slow and natural processes based on historical, backward looking. The latter relates to exogenous structures such as media and market forces, innovative design and city marketing projects. This is to say, distinctiveness can be deliberately created or actively produced with opportunity-oriented, and forward looking strategies $[15,16]$.

Achieving distinctive and competitive qualities are crucial for cities of the knowledge era, and this achievement could be realised through successfully developing and implementing place-based (tangible) and talent-based (intangible) strategies. These strategies constitute key urban policy instruments for creative city formation. Place-based strategies link creativity and place, and needed to be positioned in inter urban system. Talent-based, intangible strategies aim the incubation of creativity in and of urban place through training programs, skill centres and experimental learning by inspiring people through culture, social values, diversity and vitality [15]. As well as developing place-based and talentbased creativity strategies another important issue to focus on is the successful operation of these strategies. Some of the useful vehicles for that are arts, innovation, knowledge economy, place branding, strategies for managing growth, maintaining community diversity, and focusing on the strategies for supporting civic life alongside economic growth [14]. Within this policy spectrum place branding deserves a good deal of attention for the promotion of flourishing creative cities.

\section{Place Branding}

Creative cities are the magnets of talented immigrants, and generators of wealth. Landry [5] and Florida [4] claim that cities must compete with each other in order to attract and retain both investment and talent. As Florida [4] remarks "wherever talent goes, innovation, creativity, and economic growth are sure to follow" (p.292). This statement draws attention to the importance of harnessing, attracting, retaining, and promoting talented and creative people as a competitiveness vehicle of creative cities [17]. In this regard, place branding strategies gains particular attention to pursuit the competitive advantage providing the needs and desires of the creative class. Jensen [18] talks about place branding as a globally recognised strategy for city development, and a big advantage in tough competition for investment and talent, and sustain economic and social vitality [19]. Within the production process of places place branding requires image building. A positive city image can offer a good international position for cities. Comprehensive branding strategy is fundamental to reinvent the identity, and to rebuild or enhance the image of a city. According to Prophet [19] A strong place branding can (p.4):

- $\quad$ Shift the perception of a place that may be suffering from a poor image among external and internal constituents.

- Create a common vision for the future of the community.

- $\quad$ Provide a consistent representation of the place.

- $\quad$ Enhance its local, regional, and global awareness and position.

- Discard unfavourable stereotypes associated with a place and make it more appealing.

Place branding is not only a logo or tagline of a city, but a process of developing strategies to succeed the long-term vision and objectives. Therefore, branding should be authentic to this place, and should indicate the sense of that particular location. It should trigger the potentials and strengthen the weaknesses of the city [19]. Brands are constructed as a complex of factors named as city brand hexogen comprising people, policies, products, culture, business climate, and tourist attraction [20]. As cities are getting to resemble each other, the need for distinctiveness, reinventing, producing, or enhancing the identity force cities to construct a comprehensive strategy [21]. Cities like Barcelona, Istanbul, Rome, and Venice evolved organically and their urban identity based on built heritage, urban geography, and history. On the contrary, cities like Bilbao, Doha, Dubai, and Las Vegas are the examples of cities that their characteristics are superimposed via innovative urban design, urban regeneration, and place branding strategies that develop an artificial or produced identity [15]. For example, today Dubai is emerging as an ultra modern city in the middle of a dessert, where the construction boom only started in 1990s as a national government initiative. City plans, urban design and marketing campaigns turned Dubai into a famous city with its conceptual islands, theme parks, film studios and stylish skyscrapers. Another good example is the City of Las Vegas. It is also national government initiative aimed the economic development of the city by legalising gambling, which transformed a small railroad company town into a world famous gambling and entertainment city [22]. Santa Fe, New Mexico is a good example for a successful place branding strategy as well. The city was subjected to one of the first city-based initiatives derived from creating an architectural style and a constructed identity so called "The Myth of Santa Fe". This architectural style was created in 1930 s and widely implemented since then. The building act and urban design principles developed to support that style augmented the creation of the stylish city. Additionally successful promotion of place branding in Santa Fe exported these branding strategies to the New York City [23]. Lastly besides these large city-based projects, Guggenheim Museum at Bilbao, Spain is a successful exam- 
ple of producing an identity through innovative architectural design. The museum, which has an iconic architectural style, transformed the old industrial town into a tourist-oriented cultural city [16].

\section{Place Quality}

Place quality is another place-based strategy of creativity and an important attractor for the creative class. Place quality can be ensured by applying urban design principles, and place management strategies. Parfect and Power [24] indicate three main arenas for achievement and implementation of place quality, planning, development, and people, and states "the operation of planning policy and urban design underlines the factors of human power and the resolution of economic forces" (p.136). Increasing the quality of place is highly important both from the point of generating economic activity, and providing spatial, aesthetic, cultural, needs and psychological well being of people. Furthermore place quality is generally considered important for urban competitiveness. Development of creative capital depends on creative people, and their creativity should be harnessed with a creative milieu. Creative capital's decision of location choice is different than the financial capital. The latter seeks for the place where it is most productive, and the criteria are based on economic issues, whereas the former focuses on the ability of places to attract the creative class. Creative capital deals with amenities, opportunities, community, social and household considerations. An attractive and liveable place should contain the dimension of quality of place, such as: attributes of natural and constructed environment; diversity of people living in harmony in a tolerant environment and; vibrancy of social life, street life-outdoor activities [4]. Baum et al. [1] describe the amenities that a creative environment should have as stylish built environment, urban diversity, mix of leisure, transport rich environment, public display, and publicity. Besides, creative people want to travel easily, participate outdoor activities, urban spectacles, festivals, and sports activities, desire to display their body, and want to see others as an art object. A qualified place should be defined as unique, vibrant, and authentic; should be concerned with identity, diversity, openness, coolness, and playfulness [1].

Identity, as one of the attributes of place quality, plays a crucial role for ensuring physical, social, and psychological well-being of people in cities [25]. It is very important for ensuring their social reproduction through space. Urban identity fosters the visual image of cities, which embodies physical and symbolic importance providing social and physical attachment to that place [26]. There are many reasons for creating and enhancing identity including the continuity of culture for people not to be cut off from their past, and providing a sense of belonging. The rising global flows of capital, goods, people, and culture threatens the uniqueness of places and negatively impacts place attachment because of the homogenisation of taste, belief and cultural identity. This also threatens the authenticity and identity of places [1]. In this context, Kunzmann [7] and Healey [25] suggest that creativity is indispensable to maintain a balance between local distinctiveness and global orientation.

\section{CREATIVE INDUSTRIES}

Hall [13] and Jensen [18] indicate the value of creativity and creative industries to nations and cities. Atkinson and Easthope [14] also point out the importance of creativity for the economy by stating that "developing creative abilities is of fundamental importance in meeting the challenges of economic development via art and culture of innovation, providing a social resource of intellectual capital and creativity" (p.589). Another scholar, Kunzmann [7] supports this understanding by providing statistical evidence for the UK's particular growth experience in the creative industries of the economy during the last decade. Creative industries are the sources of cultural products [27]. These industries include various types of film/TV production, advertising, architecture, arts and crafts, new media, publishing, design, music, visual and performing arts, painting, sculpture, and activities such as movie, theatre, opera, and exhibitions [28]. They provide various tools for being distinctive, and create competitive advantage in the globalising world where every place begins to look similar [8]. Kunzmann [7] emphasises the importance of creative industries as the engines of future economic development. In parts of Europe (i.e. Germany and Britain) creative industries are growing faster than other traditional and ICT related industries. Particularly Helsinki, Malmo, Copenhagen, and Barcelona are focusing on creative industries, and developing projects on transforming large derelict industrial areas to creativity-based universities, fine art and performing schools, knowledge precincts, and urban technology parks [29]. Similar policies are also being implemented some of the capital cities in the North America and Australia (i.e. Austin, Boston, Vancouver, Adelaide, Brisbane, Darwin) $[11,14,30]$.

Many cities around the world have come to the recognition of economic and social benefits that flow from creative economy and creativity-based development strategies. Urban planners and policy makers are now developing and implementing policies to foster and promote creativity and cultural activity in cities. Evans et al. [28] states that "in global cities like New York, Berlin, and Barcelona, and in smaller centres like Austin and Newcastle, the development of the creative economy has become a strategic priority, not only for generating wealth, but also for employment opportunity" (p.2). Evans et al. [28] also indicate the importance of creative industries for place quality, innovative thinking, and formation of urban identity.

\section{THE FILM INDUSTRY}

The film industry is a significant sector of creative industries, and an effective powerhouse of economic growth [31, 32]. The film industry clusters other creative industries around itself, which constitutes a creative milieu and a magnet for creative class, and contributes to the formation of creative cities. The film industry increases economic vitality of a city by comprising various sub-sectors (e.g. photography, music, video, stagecraft, advertisement, motion picture, distribution) and large job opportunities [33]. Recent literature shows evidence that the film industry positively affects a city's reputation by escalating the recognition, which is important for building an image, and promoting the place 
through films and festivals $[34,35]$. The formation of creative class is one of the bases of moving towards a creative city, and in this regard, the film industry provides diversity in the availability of talented people such as cast and crew, art and set directors, costume designers, photography and cinematography directors, set and construction engineers, production designers, and others [36].

\section{Global Examples of Film Industry-Oriented (Creative) Cities}

Countries like the US, the UK, India, France, Spain, Canada, and Germany are the leading nations in hosting major global film industries (Table 1). In the city scale, Los Angeles (Hollywood), Mumbai (Bollywood), Auckland, Berlin, Cannes, Melbourne, Singapore and Vancouver are among the cities those purposefully focus on the film industry and make it a significant catalyst for their creative urban economies [31, 32, 37-40]. Although the film industry alone can not lead a city to become a creative one, but it is logical to argue that the film industry has invaluable contributions in the formation of a creative city $[1,39]$. There are worldwide examples of cities (i.e. Auckland, Austin, Berlin, Vancouver) those are branded as creative cities, and managed their film industries' successful contribution to their creative city formation.

Austin, Texas, one of the famous creative cities from the US, known as the 'Live Music Capital of the World', developed its film industry using the technical and social infrastructure facilities developed for the music industry [4]. For the Austin case specialisation in the music industry has become the initiator of the development of the film industry through music videos, and TV shows [42]. Although the film industry is not the primary resource of creative city formation for Austin, the sector has now become an important catalyst of attracting creative people to the city.

Berlin and Cannes, known as European capitals of creativity and talent, are the centres of creative industries such as film broadcasting, acting, literature, publishing, dance, fashion, and design. Berlin and Cannes film festivals, film studios, and film museums attract creative people to live and work in these cities, and substantially contribute to the local economies [39]. Hundreds of films are shot in and around Berlin and Cannes every year, and these cities are branded as European film hubs.

Singapore has been transmitting its economy from a knowledge-based one to a creative-based economy mainly focusing on the film industry. Although the city state is already a globally acknowledged knowledge city, the policy makers realised the importance of investing in creativity for the continuum of its global competitiveness. Singapore had a golden age of cinema in the 1950s and 1960s, especially in Malay films. The period after Singapore's independence saw a decline in film production. In the 70s and 80s Singapore probably was the only country in Southeast Asia without a film-making industry of its own. In the 1990s, things began to change. Singapore now with its recent vast investment in creative industries, mainly the film industry, by producing an

Table 1. Salient Characteristics of National Film Industries [41]

\begin{tabular}{|c|c|c|c|c|c|}
\hline Countries & $\begin{array}{c}\text { Feature Films } \\
\text { Produced (in 2005) }\end{array}$ & $\begin{array}{l}\text { Feature Films Co- } \\
\text { Produced (in 2005) }\end{array}$ & $\begin{array}{l}\text { Average Budget Per } \\
\text { FILM (\$ Million) }\end{array}$ & $\begin{array}{c}\text { Film Production } \\
\text { Investment (\$ Million) }\end{array}$ & $\begin{array}{c}\text { Market Share of Domestic } \\
\text { Products }(\%)\end{array}$ \\
\hline India & 1041 & 0 & 0.1 & 147 & 94 \\
\hline USA & 699 & 0 & 19.9 & 13945 & 93 \\
\hline Japan & 356 & 0 & 5.2 & 1841 & 41 \\
\hline UK & 124 & 87 & 8.4 & 1043 & 34 \\
\hline Germany & 103 & 43 & 8.2 & 845 & 17 \\
\hline Italy & 98 & 30 & 2.7 & 267 & 25 \\
\hline Brazil & 90 & 0 & 1.2 & 111 & 10 \\
\hline Australia & 32 & 3 & 3.7 & 81 & 3 \\
\hline Hungary & 26 & 9 & 0.6 & 14 & 12 \\
\hline Turkey & 25 & 4 & 1.8 & 55 & 42 \\
\hline Romania & 20 & 11 & 0.7 & 14 & 5 \\
\hline Norway & 19 & 4 & 1.9 & 36 & 14 \\
\hline Finland & 13 & 5 & 2.1 & 27 & 15 \\
\hline Singapore & 8 & 2 & 0.4 & 4 & 3 \\
\hline New Zealand & 5 & 2 & 57.8 & 289 & 0 \\
\hline
\end{tabular}


Table 2. Development of Turkish Film Industry Between 1996 and 2006 [52]

\begin{tabular}{|c|c|c|c|c|c|c|c|c|c|c|}
\hline Year & $\begin{array}{l}\text { Feature } \\
\text { Films } \\
\text { Produced }\end{array}$ & $\begin{array}{l}\text { Feature } \\
\text { Films } \\
\text { Released } \\
\text { (Domestic) }\end{array}$ & $\begin{array}{l}\text { Feature } \\
\text { Films } \\
\text { Released } \\
\text { (Foreign) }\end{array}$ & $\begin{array}{l}\text { Feature } \\
\text { Films } \\
\text { Released } \\
\text { (Total) }\end{array}$ & $\begin{array}{c}\text { Admissions } \\
\text { (Million } \\
\text { People) }\end{array}$ & $\begin{array}{c}\text { Admissions } \\
\text { (Domestic } \\
\%)\end{array}$ & $\begin{array}{l}\text { Box Office } \\
\text { (\$ Million) }\end{array}$ & Theatres & Screens & $\begin{array}{c}\text { Average } \\
\text { Ticket } \\
\text { Price (\$) }\end{array}$ \\
\hline 2006 & 47 & 34 & 204 & 238 & 34.9 & 51.1 & 193.5 & 411 & 1,299 & 5.5 \\
\hline 2005 & 25 & 27 & 194 & 221 & 27.3 & 42.0 & 141.0 & 389 & 1,114 & 5.2 \\
\hline 2004 & 19 & 18 & 189 & 207 & 29.7 & 37.4 & 141.8 & 375 & 1,085 & 4.8 \\
\hline 2003 & 25 & 16 & 172 & 188 & 24.6 & 22.9 & 103.9 & 343 & 995 & 4.2 \\
\hline 2002 & 22 & 9 & 159 & 168 & 23.5 & 8.5 & 73.0 & 335 & 941 & 3.1 \\
\hline 2001 & 19 & 17 & 137 & 154 & 28.2 & 27.0 & 76.2 & 310 & 784 & 2.7 \\
\hline 2000 & 29 & 15 & 157 & 172 & 25.3 & 23.8 & 67.3 & 284 & 651 & 2.7 \\
\hline 1999 & 20 & 14 & 141 & 155 & 23.9 & 10.5 & 59.0 & 287 & 505 & 2.5 \\
\hline 1998 & 22 & 10 & 162 & 172 & 21.0 & 14.1 & 46.3 & 252 & 447 & 2.2 \\
\hline 1997 & 25 & 13 & 182 & 195 & 16.1 & 10.2 & 34.7 & 211 & 309 & 2.1 \\
\hline 1996 & 37 & 9 & 162 & 171 & 15.1 & 19.7 & 30.1 & 242 & 417 & 2.0 \\
\hline
\end{tabular}

average of five feature films a year during the last decade, is now moving towards to become a creative city [43].

Vancouver occupies a distinctive place within the highly developed Canadian film industry. Vancouver's success in the industry mainly depends on: the west coast film-making and strong ties to Hollywood; promotion and perception of movies by the provincial government; province's natural assets, and variety of landscapes; and the success of luring the runaway productions from Hollywood with tax-credit programs as an inducement to both foreign and indigenous producers [32]. In 2005 city managers initiated a creative city taskforce and developed strategic plans to establish Vancouver as a creative city [44]. After several of years of persistent implementation of creativity strategies, Vancouver now gained a worldwide recognition as a creative city with a high level of liveability offer to its residents and its success in both national and international competitiveness in the film industry.

After the movies of Lord of the Rings, King Kong, Chronicles of Narnia, River Queen, and World's Fastest Indian shot in different locations in New Zealand, particularly Auckland, Wellington and Christchurch are started to be seen among the popular cities for international film makers. The natural amenities of the region and high capacity of technical facilities for filming are promoted film production in Auckland [37, 45]. Auckland is now developing strategies to become a creative city and highly benefiting from the achievements of its rapidly emerging film industry [46].

\section{Turkish Film Industry}

Turkey has a long history and experience in film making, which the film making journey was started back in 1914 and until the end of 1990s about 5,000 films and TV serials were produced. [47, 48]. Majority of the companies of film industry are located in Istanbul mainly in the district of Yesilcam. Turkey has an attractive physical and social environment for the development of film industry providing the national and international interactions with various film festivals of every genre, and international film markets. Every year on average
35 film festivals are organised nationally and in conjunction with other countries such as Germany, Black Sea Region, and Far Eastern countries [49]. These activities provide opportunities for creative Turkish people to exercise their talents, to interact with other people from different countries and organisations. Film festivals generate additional revenues bringing prestige to the location hosting them [50]. In this context as having large numbers of activities organised annually, Turkey provides diversity to incubate creativity. Major events such as International Istanbul Film Festival, Antalya Golden Orange Film Festival, Adana Golden Ball Film Festival, and festivals in other major cities contribute to the desired diversity and energy for economic activity, tourism and creativity [51]. Furthermore other international events in the US, Europe or Australia such as Turkish film weeks organised in London, Boston, Sydney and so on provide a good reputation and cultural interactions for the cities hosting these events.

On average every year 30 feature films produced in Turkey. During the last decade an increasing number of foreign feature films, documentary films, and TV programs are shot in different locations in Turkey. Documentary films are the mostly produced genres with 101 documentary films produced out of 123 total foreign productions between 1996 and 2007 [51]. Besides documentary films there are a number of foreign feature films and co-productions shot in Turkey as well. Turkey has a growing film industry with the increase in the number of cinemas, admissions, and films produced and released each year (Table 2).

During the last two decades film industry in Turkey has started to go through considerable changes to become competitive in the global market. The national and local governments are now have schemes to support film industry, and pushing this industry to become an important sector of local economic development [53]. In 1990 Turkey has become a member of the Council of European Fund for Cinematographic Works (Eurimages). Since then 57 Turkish movies, seven of them are co-production with France, Greece, Italy, Germany, and Hungary, financially supported by this 
council [54]. These projects were highly successful in national and international film festivals. Turkish artists, directors living in Europe such as Ferzan Ozpetek (director) in Italy, Fatih Akin (director) and Sibel Kekilli (actress) in Germany, strengthened international relationships and contributed in co-productions. During the last decade film industry in Turkey is growing with an average rate of 169 percent, most recently the share of film industry increased from $\$ 5$ billion in 2006 to $\$ 11$ billion in 2007 [53]. Furthermore in recent years Turkish films are becoming highly successful in famous film festivals. Dry summer (1964) by Metin Erksan, and Head-on (2004) by Faith Akin awarded with Golden Bear at the Berlin Film Festival. The Way (1982) by Serif Goren received the Golden Palm Award at the Cannes Film Festival. Distant (2003) by Nuri Bilge Ceylan received the Big Jury Award at the Cannes Film Festival [48]. The Edge of Heaven (2007) by Fatih Akin won the Best Screenplay Award at the Cannes Film Festival, and most recently Three Monkeys (2008) by Nuri Bilge Ceylan received the Best Director Award at the Cannes Film Festival.

Growing creative human resources, wide range of cultural activities, festivals, geographical and architectural assets, international relationships, the demand of the local interest groups, and developing technical infrastructure are the positive signs of emerging industrialisation and globalisation of Turkish national film sector. Of course there are many obstacles in front of Turkey in becoming a globally successful film centre. The lack of corporate governance and identity, legal framework, government incentive schemes, and attractive custom taxes are among the major obstacles [55]. The disorganised structure of the governance also creates problems for foreign film companies in different stages of the process - for example, taking permission to shoot films in the country, legal procedures for employing foreign actors and set crew [55]. Another problem is the low domestic demand from the sector; mainly because of the socio-economic income structure, number of TV channels, pirate movie copies, and high tax on movie admissions [56].

\section{Antalya: An Emerging Eurasian Film Centre}

Antalya is a south-western city of Turkey with a population almost reaching to two million people. The city is specialised in tourism, agriculture, trade, and the film industry as major economic activities. Tourism sector in Antalya City and its surrounding region has experienced a significant boom since 1980s, which enabled Antalya to become a centre of tourism in the Mediterranean region. The city, also known as the 'Pearl of Turkish Riviera', has approximately half a million bed capacity licensed by the Ministry of Tourism and Culture [57]. During the last decade as a result of the city's natural characteristics, cultural resources, investments, technical infrastructures and the Golden Orange Film Festival, a film industry has rapidly developed in Antalya. This new film centre more or less works as a sub centre for countries major film-making centre, Yesilcam, Istanbul. There are a number of reasons for Antalya's recent emergence as a new film centre for Turkey. Firstly, its close proximity to Middle Eastern cities such as Abu Dhabi, Beirut, Dubai, and Tel Aviv plays an important role, as there are international projects underway with Dubai interacting with major film companies (Warner), to built local versions of American film industry such as film academies (overseas campus of New York University), TV program studios, (MTV), and Hollywood Universal Studios [58]. Secondly, Antalya's strategic location in the country provides advantages for connections with Cappadocia and south-eastern Anatolian picturesque landscapes, and architectural assets especially for domestic TV serials and movies (i.e. UNESCO World Heritage listed Cappadocia, Mardin and Goreme cities and towns) Thirdly, Antalya has rich natural and cultural assets that provides a good location option for film makers. The city has rich variety of archaeological sites such as Aspendos and Side, historic buildings and districts such as Kaleici city centre, monumental buildings, mosques, various waterfalls, escarpments, natural parks, mountains and forests. Most importantly Antalya is suitable for shooting films with its mild climate with 300 days of sunshine with right angle and brightness [59]. Being a major international tourism destination, Antalya provides rich accessibility options through global aviation networks to many cities worldwide. Recently the capacity of Antalya international airport has expanded, and the construction of the second airport has been completed. National high-speed train project is on the agenda with an aim to decrease the travel time to other important national destinations, and enhance its connectivity with the major film and cultural centre, Istanbul [60]. Lastly Antalya, in the film industry, highly benefited from Istanbul's experiences and support. Films produced in Istanbul and the creative people of Istanbul's film industry contributed to the success of the Golden Orange Film Festival, and helped in developing its international reputation.

Antalya's first endogenous film industry companies dates back to 1957 . The first film company was founded in the city by a famous film director, Behlül Dal, aiming to make Antalya a film city. Dal worked towards turning Antalya into a city as a natural film plateau for Turkish movie makers [49]. This dream continued with establishing the first film festival in Turkey. Film festivities started in historical Aspendos theatre in 1950s. In 1964 Avni Tolunay, the Mayor of Antalya, turned these events into a film festival, Antalya Golden Orange Film Festival. The festival aimed to promote Turkish film sector, to encourage national film producers for high quality projects and to provide a platform for international interactions [61]. This aim is achieved when the Golden Orange Film Festival became an international event in 2005 [62]. In 2007 during the festival, 170 films were shown, 108 of them were foreign films from Europe, Asia and Africa, and awards were handed out in 24 categories [62]. Another important achievement to support the film industry development, was the establishment of an international film market in Antalya that is also important for creative city formation in terms of providing cultural and commercial interactions of creative people and filming companies. In 2006 Golden Orange Film Festival became a member of the International Eurasia Film Market and started to host this market during the festival. In 2006, from 78 cities around the world, 229 foreign company representatives, producers, consultants, distributors, and institutions participated to this film market. This interaction is resulted in over 50 co-production agreements and nearly 40 film sale [63]. The multilevel structure of the Golden Orange with its sub-events, contributes to city's economy, tourism, and cultural vibrancy with meetings, seminars, exhibitions, concerts. The Festival and market together form network of formal and informal connec- 
tions and creative interactions [62]. Especially Golden Orange fosters the local interest in the film industry, and engages local residents in festival activity organisation, which also establishes a volunteer festival community. As Kunzmann [7] argues branding through culture and urban spectacles are important vehicles for the creative development of cities. At that point Golden Orange being a major international film festival in Turkey has important contributions in attracting creative class, increasing the recognition of Antalya, and enhancing the activities of creative industries [64]. This film and festival culture of the city, along with the history and natural beauty is a strong point of origin for the branding process of Antalya. Last decade witnessed an increase in the new film industry investments in Antalya. In 1999, Tekfen and American Golden Horn Film companies jointly built an international film studio in Antalya [65]. Antalya Studios is a large complex with soundstages, star suites, workshops, costume, make up and hair facilities. A number of blockbuster movies are shot in the studios including Arabian Nights in 2000, and GORA in 2004 [66]. In 2006, in Antalya and its hinterland nine productions were shot by Egyptian, German, Canadian, Taiwanese, Hungarian and English film companies, eight documentaries, and a $35 \mathrm{~mm}$ film. In 2007, the total number of foreign productions, including documentaries, DVD movies, and TV programs, were shot by European, Australian, Canadian, and American film companies was 19 [51].

As mentioned in the previous sections importance of creative class for the formation of a creative city is evident, and besides being a suitable hotspot for the film industry formation, Antalya provides a quality of place and life to its creative class. The city has much to offer to talented people with its natural and constructed amenities. Internationallyacclaimed marina, old town with traditional architecture, international boutique hotels, and the bohemian lifestyle suits well with the experimental lifestyles of the creative class. The city presents a lively nightlife with various night clubs and entertainment centres. Antalya is highly tolerant to sexual preferences; there are a number of hotels and bars serving with gay-lesbian staff for their gay-lesbian and straight customers [67]. Antalya is a city of festivals and plays a major role for the social interactions with many national and international events (Golden Orange Film Festival, Eurasia International Film Festival and Film Market, Aspendos Opera and Ballet Festival, Antalya Piano Festival, Antalya International Sand Sculpture Festival - Lara Sand City, Side International Art and Culture Festival). The city also hosts a large number of sportive activities such as Alanya International Beach Volleyball Tournament, Alanya Triathlon Premium European Cup, golf tournaments, archery, tennis, and skiing contests. Antalya is preparing to host World Rally Championship in 2008 and World Basketball Championship in 2010. The city also actively cooperates with other creative cities such as Austin, which is one of the eight sister-cities of Antalya. In 2006, mayors of Antalya and Austin made a commitment in exchanging each others creative city experiences and developing joint projects to foster their relationship [68].

According to Friedmann [69] creative work requires public support and priority consideration should be run on nurturing the creativity rather than attracting creative class. The lack of endogenous power, such as creative class inhabiting or working in Antalya weakens the possibility of forming creative city. In this context, it can be said that Antalya has disadvantages in terms of not having enough creative human resources. Most of the actors, directors, writers and so on live in Istanbul mainly because of the larger labour market in Istanbul. However, there are quality tertiary educational facilities related to creative industries in the city such as Akdeniz University Fine Arts Faculty, and Serik Vocational School also providing education on film making, movie and TV programs. The city provides growing job opportunities for creative class at Antalya Technopolis, and various fairs and congresses [70, 71].

Despite the advantages of the creative city mission and the film industry development goals, Antalya has many obstacles in front of being a film industry-oriented creative city and a Eurasian film centre [68]. The major obstacle is that at present there is not an advantageous milieu for filming companies to locate in Antalya. Majority of the companies, social associations, artists and directors live and work in Istanbul which is the major centre of film-making due to rich technical and social infrastructure. Although Antalya has the biggest film studio of Turkey, there are not many film production or distribution companies located in Antalya. The companies that are based on Istanbul casually use Antalya for shooting their outdoor scenes and the reputation of Golden Orange and Eurasia Film Market's opportunities for international interactions. Another major obstacle is that Antalya's organisational capacity is limited since the city has not got civic institutions such as any film association, union, or funding body apart from Antalya Foundation of Culture and Arts [52]. All of these strengths and constraints provide an overview of Antalya's current situation in its adventure in becoming a film industry-oriented creative city and a Eurasian film centre. Besides the strong potential in the film industry formation as part of its creative city vision, these initiatives also contribute to the further development of the film industry-oriented tourism sector in Antalya.

\section{CONCLUSIONS}

Antalya is working towards to develop its film industry since Behlül Dal's vision of making Antalya a cinema city in 1957. After more than 50 years Antalya progressed a lot in that direction. In recent years Antalya's rapidly increasing global connections brought new creative industrial activities to the city. The vision of being a film city is manipulated in connection with the creativity strategies to make Antalya film industry-oriented creative city and a Eurasian film centre. For Antalya the film industry is particularly seen as a relevant sector both for city's local economic development and creative city formation. Antalya has a substantial potential to become an attractive place for creative industries, and develop into a creative city. However it is still not easy to pinpoint where Antalya stands in her long creative city journey. The preliminary investigation points out some strength and also equivalent level of weaknesses in Antalya's path. Further in depth empirical and policy research is needed to be able to comment precisely on how successful is Antalya's path towards becoming a film industry-oriented creative city and a Eurasian film centre. However, the following recommendations could be good points of start in strategising Antalya's development and its transition to a Eurasian film centre. 
Firstly, for Antalya to be able to specialise successfully in the film industry, a well designed place branding strategy, which would increase the global positioning of the city is needed. On the other hand, place quality is also important as an inducement of attracting the film industry, and creative class to live and work in the city. The city should be defined with a brand consistent of its historical values, geographical properties, and changing socio-economic realities. Antalya also could further develop its global connections by taking active roles in creative city networks.

Secondly, global examples of film industry-oriented creative cities suggest a potential correlation between a strong film industry and the creative city. The film industry plays curial role in creative city formation with a potential of attracting creative class and providing creative milieu for developing other creative industries. Moreover, the industry enhances global networks, social and economic interactions of creative people, creates vitality and diversity through film festivals and markets and promotes the place through the films. Antalya could benefit from the learnings of other city experiences in becoming a film industry-oriented creative city. As observed from the cases of Vancouver and Auckland, these cities developed their creative city strategies based on different catalysts. Vancouver used the potential of being close to Hollywood, and the generous government support. Auckland used the popularity of the movie 'Lord of the Rings' and the potential of New Zealand's natural assets. Antalya's assets and amenities, international recognition of the Golden Orange Film Festival, and regional location advantages can be used as a catalyst to become an (inter)national film industry centre. Certainly in such big transition Antalya needs all the support of the Istanbul film industry and the national and local governments.

Thirdly, at the earlier stages of the development in Antalya, the film industry should be supported through the incentives of government and film associations. The lack of a sound city marketing perspective results in a variety of interconnected problems. These problems include loosing local identity or authenticity of place, which is also a danger in repelling the creative class. There needs to be strategic organisation principles to steer policy making efforts to enhance or reinvent the urban identity. More detailed studies are needed to question the strategies of Antalya in making it unique, attractive, and valued for business, consumers, residents, and visitors. Implementation of the branding as part of Antalya's ongoing creative city development, and stakeholders and policy makers' roles in realising the branding strategy should be clearly defined.

Lastly, although competitiveness gains a great importance for creative cities, there should be a balance between endogenous growth and competitiveness. It is good to be aware of what others are doing, however developing strategies depending on global benchmarking may stop local innovativeness. It is highly important to invest on local talent development through education and training which reduce the dependency on exogenous talent. Antalya needs to develop a critical and creative thinking to give unique and distinctive responses to problems faced during the construction of a film industry-oriented creative city and transition to a Eurasian film centre, in a different way rather than letting the global transformations control the whole development.

\section{REFERENCES}

[1] Baum S, Gleeson B, Horton S, Velibeyoglu K, Yigitcanlar T. The role of community and lifestyle in the making of a knowledge city. Urban Res Prog Policy Pract Paper 2007; 2: 1-87.

[2] Yigitcanlar T, Velibeyoglu K, Baum S, Eds, Knowledge-based urban development: planning and applications in the information era. Hershey, PA: Information Science Reference 2008.

[3] Yigitcanlar T, O'Connor K, Westerman C. The making of knowledge cities: Melbourne's knowledge-based urban development experience. Cities 2008; 25(Pt 2): 63-72.

[4] Florida R. The rise of the creative class: And how it is transforming work, leisure community and everyday life. New York: Basic Books 2002.

[5] Landry C. The creative city: A toolkit for urban innovators. London: Earthscan 2000.

[6] Landry C. Lineages of creative city [article on the internet]. 2006; [Retrieved on Jan 5, 2008]. Available from: http://www.comedia. org.uk

[7] Kunzmann K. Culture, Creativity and spatial planning. Town Plan Rev 2004; 75(Pt 4): 383-404.

[8] Landry C. Rethinking creative city [article on the internet]. 2003; [Retrieved on Jan 5, 2008]. Available from: http://www.comedia. org.uk

[9] Yigitcanlar T, Velibeyoglu K, Baum S, Eds. Creative urban regions: Harnessing urban technologies to support knowledge city initiatives. Hershey, PA: Information Science Reference 2008.

[10] Landry C. The art of city making. London: Earthscan 2006.

[11] Andrew J, Spoehr J. Thinking strategically-Acting creatively: Conceptualizing creativity in Adelaide. Proceedings of the State of Australian Cities 2007 National Conference; University of South Australia and Flinders University, Adelaide, Australia. 2007; 82230 .

[12] Durmaz B, Velibeyoglu K, Yigitcanlar T. Emergence of a creative city: Antalya a film-induced tourism centre. In: Metin K, Nazmi K, Eds. Proceedings of the 4th World Conference for Graduate Research in Tourism, Hospitality and Leisure; 2008 Apr 23-27: Otium Hotel Zeynep, Antalya, Ankara, Turkey 2008; 552-67.

[13] Hall P. Creative cities and economic development. Urban Stud 2000; 37(Pt 4): 639-49.

[14] Atkinson R, Easthope H. The consequences of the creative class: The pursuit of creativity strategies in Australia's cities. Proceedings of the State of Australian Cities 2007 National Conference; University of South Australia and Flinders University, Adelaide, Australia. 2007; 586-97.

[15] Turok I. The resurgence of former industrial cities: How important is distinctiveness? Themed session: The distinctive city. Leverhulme international symposium. The resurgent city, 2004 Apr 1921; London School of Economics, 2004. Available from: http:// www.lse.ac.uk

[16] Gospodini A. Urban morphology and place identity in European cities: Built heritage and innovative design. J Urban Des 2004; 9(Pt 2): 225-48.

[17] Yigitcanlar T, Baum S, Horton S. Attracting and retaining knowledge workers in knowledge cities. J Knowl Manage 2007; 11(Pt 5): 6-17.

[18] Jensen O. Branding the contemporary city: Urban branding as regional growth agenda? Plenary paper for regional studies association conference regional growth agendas. Aalborg, 2005; 28-31.

[19] Prophet M. Branding Your City Report [report on the internet]. 2006 March; [Retrieved on Dec 15, 2007]. Available from: http://www.ceosforcities.org

[20] Anholt S. City Brands Index Report: How the world sees its cities [report on the internet]. $20062^{\text {nd }}$ ed; [Retrieved on Dec 15, 2007]. Available from: http://www.citybrandsindex.com

[21] Mccarthy J. Regeneration of cultural quarters: Public art for place image or place identity? J Urban Des 2006; 11(Pt 2): 243-62.

[22] Douglass W, Raento P. The tradition of invention: Conceiving Las Vegas. Ann Tour Res 2004; 31(Pt 1): 7-23.

[23] Wilson C. The myth of Santa Fe: Creating a modern regional tradition. Albuquerque: University of New Mexico Press 1997.

[24] Parfect M, Power G. Planning for urban quality: Urban design in towns and cities. London: Routledge 1997.

[25] Healey P. Place identity and governance: Transforming discourses and practices. In: Hillier J, Rooksby E, Eds. A Habitatus: Sence of place. Hampshire: Ashgate Publishing 2005; pp. 189-219. 
[26] Saleh M. Place identity: The visual image of Saudi Arabian cities. Habitat Int 1998; 22(Pt 2): 149-64.

[27] Baum S, Yigitcanlar T, O'Connor K. Creative industries and the urban hierarchy: The position of lower tier cities and regions in the knowledge economy? In: Yigitcanlar T, Velibeyoglu K, Baum S, Eds. Knowledge-based urban development: planning and applications in the information era. Hershey, PA: IGI Global 2008; pp. 4257.

[28] Evans G, Foord J, Gertler M, Tesolin L, Weinstock S. Strategies for creative spaces and cities: Lessons learned [report on the internet]. [Retrieved on Jan 29, 2008]. Available from: http://www. web.net

[29] Kunzmann K. Creativity in Planning: A fuzzy concept [article on the internet]. 2005 March; [Retrieved on Jan 15, 2008]. Available from: www.nsl.ethz.ch

[30] Luckman S, Gibson C, Lea T, Brennan-Horley C. Darwin as 'Creative Tropical City': Just how transferable is creative city thinking?: Proceedings of the state of Australian cities 2007 National Conference; University of South Australia and Flinders University. Adelaide, Australia, 2007; 370-6.

[31] Bassett K, Griffiths R, Smith I. Cultural industries, cultural clusters and the city: The example of natural history film-making in Bristol. Geoforum 2002; 33: 165-77.

[32] Gasher M. Hollywood North: The feature film industry in British Columbia, Vancouver: UBC Press 2002.

[33] Di Persio C, Horvath G, Wobbeking R. The impact of the film industry on Colorado [research paper on the internet]. 2003 June; [Retrieved on Jan 24, 2008]. Available from: http:// thecreativecoalition.org

[34] Beeton S. Film-induced tourism. Clevedon, Buffalo: Channel View Publications 2005

[35] Karpathiotaki T, Papatheodorou A. Film induced tourism development and policy making: The case of crete. Proceedings of the first conference of the international association for tourism economics; 2007 Oct 25-27; Palma de Mallorca, Spain. [Retrieved on Feb 4, 2008]. Available from: http://trioptron.org

[36] Hayward S. Cinema studies: The key concepts. London: Routledge 2000.

[37] Croy G. The Lord of The Rings, New Zealand and Tourism: Image Building with Film [Working Paper Series on the internet]. 2004; [Retrieved on Feb 5, 2008]. Available from: http://www.buseco. monash. edu.au

[38] Elsaesser T. European cinema face to face with Hollywood Amsterdam. Amsterdam: Amsterdam University Press 2005.

[39] Kraetke S. City of Talents? Berlin's Regional Economy, SocioSpatial Fabric and 'Worst Practice' Urban Governance. Int J Urban Reg Res 2004; 28(Pt 3): 511-29.

[40] Minocha S, Stonehouse G. The "learning trap": A Bollywood frame for strategic learning. Manage Dec 2006; 44(Pt 10): 1344-62.

[41] Screen Digest. World film production/distribution profile. [report on the internet]. 2006 June; [Retrieved on March 6, 2008]. Available from: http:// www.fafo.at

[42] Yigitcanlar T. The making of urban spaces for the knowledge economy: Global practices. In: Al-Furaih I, Sahab A, Hayajneh A, Abdullah A, Ibrahim M, Thalha M, Eds. Knowledge cities: Future of cities in the knowledge economy. Scholar Press: Selangor, Malaysia 2007; 73-97.

[43] Wong C. Knowledge economy in transition: The case of Singapore. In: Yigitcanlar T, Velibeyoglu K, Baum S, Eds. Knowledge-Based Urban Development: Planning and applications in the information era. Hershey, PA, Information science reference 2008; pp. 58-80.

[44] Creative city taskforce. A new culture plan for Vancouver: 20082018 [report on the internet]. 2008 Jan; [Retrieved on Jan 30, 2008]. Available from: http://vancouver.ca

[45] New Zealand government. New Zealand tourism strategy 2015 [report on the internet]. 2007 Nov 7; [Retrieved on Feb 28, 2008]. Available from: www.nztourismstrategy.com
[46] Auckland City, Starkwhite. Rethinking Auckland as a creative city: Concepts, Opportunity, Practical Steps [report on the internet] 2002 Aug; [Retrieved on Feb 1, 2008]. Available from: www.auckland city.govt.nz

[47] Directorate general of press and information. Turkish cinema [report on the internet]. $2008 \mathrm{Feb}$; [Retrieved on March 6, 2008] Available from: http://ww.byegm.gov.tr

[48] Ozguç A. Sekseninci Yilinda Turk Sinemasi. Ankara: Kultur ve Turizm Bakanligi Yayinlari 1995.

[49] Kamera A. [Retrieved on Feb 27, 2008]. Available from: http:// www.kameraarkasi.org/festivaller.html

[50] Andersen V, Prentice R. Festival as creative destination. Ann Tour Res 2003; 30(Pt 1): 7-30.

[51] Cine Turk, data base of Turkish cinema [homepage on the internet [Retrieved on March 1, 2008]. Available from: www.cineturk.org

[52] Yavuz D. Antrakt Cinema Newspaper. 2006 Dec 29; [Retrieved on Feb 29, 2008]. Available from: http://www.sadibey.com/dosyalar

[53] State Planning Organisation. 9th development plan [official gazette on the internet]. 2006 July 1; [Retrieved on March 6, 2008]. Available from: http://ekutup.dpt.gov.tr/plan/plan9.pdf

[54] Eurimages, Council of Europe, European Cinema Support Fund [homepage on the internet]; [Retrieved on March 14, 2008]. Available from: coe.int/T/DG4/eurimages

[55] Scriptwriters association of Turkey. Tax council report. [Retrieved on Feb 29, 2008]. Available from: http:// www.senaryo.org.tr

[56] Çilingir S. Turkish Cinema Industry Roadmap [report on the internet]. 2006; [Retrieved on Feb 23, 2008]. Available from: www.sadibey. com/dosyalar

[57] Antalya Metropolitan Municipality. Antalya Strategic Plan [report on the internet]. 2006 July; [Retrieved on Feb 28, 2008]. Available from: www.antalya.bel.tr

[58] Guardian. Guardian unlimited daily newspaper. 2007 Dec 9; [Retrieved on Feb 1,2008]. Available from: http://film.guardian.co.uk

[59] Ministry of culture and tourism. Republic of Turkey ministry of culture and tourism [homepage on the internet]; [Retrieved on Feb 8, 2008]. Available from:http://www.kultur.gov.tr

[60] Arkitera Architecture Centre. Arkitera Architecture Centre Press Release. 2008 Jan 24; [Retrieved on Feb 1, 2008]. Available from: http:// www.mimarlikmerkezi.org

[61] Ozguç A. Antalya film Festivalinin 40 Yili. Antalya: Antalya Kültür Sanat Vakfi Kultur Yayinlari 2003.

[62] AKSAV. Antalya Foundation of Culture and Art. [homepage on the internet]; [Retrieved on March 1, 2008]. Available from: www.aksav.org.tr

[63] TURSAK. Turkish Foundation of Cinema and Audiovisual Culture. [homepage on the internet]; [Retrieved on March 12, 2008]. Available from: http://altinportakal.tursak.org.tr

[64] Gotham K. Theorizing urban spectacles Festivals, tourism and the transformation of urban space. Cities 2005; 9(Pt 2): 225-46.

[65] Hurriyet. Hurriyet Turkish daily newspaper. 1998 Nov 8; [Retrieved on Feb 1, 2008]. Available from: http://arama.hurriyet. com.tr

[66] Antalya Film Studios [homepage on the internet]; [Retrieved on Feb 1, 2008]. Available from: www.antalyastudios.com

[67] Hurriyet. Hurriyet Turkish daily newspaper. 2007 May 30; [Retrieved on Feb 1, 2008]. Available from: http://arama.hurriyet. com.tr

[68] Antalya metropolitan municipality. Antalya city vision project. [homepage on the internet]; [Retrieved on Feb 1, 2008]. Available from: www.antalyakentvizyonu.com

[69] Friedmann J. The Wealth of Cities: Towards an assets-based development of newly urbanizing regions. Dev Change 2007; 38(Pt 6): 987-98.

[70] Akdeniz University. Antalya Technopolis. [homepage on the internet]; [Retrieved on Feb 1, 2008]. Available from: www.akdeniz.edu.tr

[71] Antalya fair management and investment inc. [homepage on the internet]; [Retrieved on Feb 1, 2008]. Available from: http://www. anfas.com.tr 